Unity Journal

Vol. III, 40-50, 2022

Doi: https://doi.org/10.3126/unityj.v3i01.43314

Prithvi Narayan Shah Research Center

Directorate General of Military Training, Nepali Army

Kathmandu, Nepal

\title{
Millennium Challenge Corporation: Interpretations and Implications for the National Security of Nepal
}

Ashis Adhikary

\section{Abstract}

The interpretations of $M C C$ in the Nepali "bazaar" comprise three themes: sovereignty, geopolitics, and governance. This study reveals that these diverging interpretations of $M C C$, based upon these themes, pose implications to the national security of Nepal. First, it poses a challenge to the unity of the Nepalese people. Second, the composed narratives of the United States against China under a geopolitical theme construct another challenge in the conduct of Nepal's foreign policy. Last, the absence of interpretations based on economic development perspectives creates a socioeconomic challenge related to poverty and unemployment. Formal political synonymy, disdain of United States against China narrative, and new narratives of development are crucial to gradually disparage these challenges. Epistemologically, this paper is interpretative (constructive) and uses an inductive, qualitative method of study. To do so, it collects secondary data in the form of expert interviews from the social, political, legal, and economic spaces of society.

Keywords: Millennium Corporation, sovereignty, governance, national security,

\section{Introduction}

Historically, Nepal's national security was centered on the security of the state and the heads of state during different regimes. In the Rana and Panchayat regimes, security arrangements like laws, policies, strategies, rules and procedures, institutional mechanisms, capabilities, resources, and monitoring provisions were narrowly focused (Uprety, 2019, p. 2). Security was viewed narrowly, decision-makers were less informed and engaged, and the state made no systematic efforts to establish institutional arrangements. Now, the Constitution of Nepal, 2015 AD, has internalized that the state must promote and protect national unity, social solidarity, and cohesion in the backdrop of the ethnic, linguistic, cultural, and religious diversity that Nepal possesses.

As per the National Security Policy published by the Ministry of Defense in 2016 AD, national security implies safeguarding a country in geographical, social, economic, and political perspectives as an integrated framework of overall structures (Ministry of Defense, 2016, p. 3). The fundamental objectives of national security policy include freedom, sovereignty, national unity, territorial integrity, human rights, a foreign policy based on the UN charter and 
Panchasheel, and protection of the interests of Nepal.

However, it is imperative to point out that there are many issues and challenges to Nepal's national security that are emerging from the interplay between powerful countries. Its geographical position between two different political systems, emerging as global powers, has attracted both regional and global interest in this region. In the meantime, the international system is experiencing changes in the balance of power as the United States, which led the unipolar world after the cold war, has a new challenger as the People's Republic of China. Both powers are enforcing themselves in world politics through distinct policies: the Belt and Road Initiative (BRI) by China; the Indo-Pacific Strategy (IPS) and the Millennium Challenge Corporation (MCC) by the United States.

The emergence of MCC has traversed significant interpretations in the Nepali bazaar. The primary objective of this study is to elucidate these interpretations and conduct their thematic analysis. Then, it assesses implications for the national security of Nepal based upon those interpretations and corresponding themes. The paper is organized into five different parts. The first part introduces the national security of Nepal and the implications of the MCC. The second part briefly explains the history of MCC in Nepal. The third part reviews existing literature and describes the methodology of this study. The fourth part analyzes interpretations of the Nepali bazaar and presents different themes of those interpretations. Finally, the fifth part assesses implications for the national security of Nepal based upon those themes and interpretations.

\section{Nepal and the MCC}

The Millennium Challenge Corporation was established by the U.S. Congress in January 2004 and describes itself as an innovative and independent U.S. foreign assistance agency working in the fight against global poverty (Millennium Challenge Corporation, 2021, para 1). Nepal formally signed the 500 million USD compact with MCC in 2017 $\mathrm{AD}$, with a self-contribution of an additional 130 million USD. The MCC's support goes to constructing around $300 \mathrm{~km}$ of $400 \mathrm{kV}$ transmission line from Lapsiphedi to Sunawal with 3 substations and maintaining around $300 \mathrm{~km}$ of road in various alignments. Later, in 2019, Nepal and MCC signed the program implementation agreement. Therefore, there are two important agreements related to MCC: first, the MCC agreement, also called the compact, and second, the implementation agreement, also called the program implementation agreement.

Both the compact and the program implementation agreement have traversed a series of controversies. The genesis of this controversy started after US Assistant Secretary of State for South Asia, David J. Ranz, stated MCC as an initiative under the Indo-Pacific Strategy. The development of such controversy into political differences complicated the process of parliamentary ratification of the MCC agreement. Though it was registered in the parliament by then Finance Minister Yubaraj Khatiwada for ratification, it was not presented before the House of Representatives for discussion. The ruling government's task force comprising former Prime Minister Jhala Nath Khanal, former home minister Bhim Rawal, and serving foreign minister Pradeep Gnawali also got divided over MCC. 
Amid domestic political chaos and a writ against the dissolution of parliament in the supreme court, the MCC remained aloof for a certain period. In the meantime, there were agitations against MCC by cadres of political parties. On September 3rd, 2021, the Nepal government corresponded with the MCC headquarters, seeking answers about the dubious points of the MCC compact. Some of the issues raised in the letter included whether MCC is part of the Indo-Pacific strategy, who conducts the audit, and whether this compact supersedes Nepali law and the constitution. The MCC headquarters replied on September 8, 2021, with the following answers: MCC is not a part of the Indo-pacific strategy; the Nepali constitution is above the MCC compact; and the ownership of the intellectual property remains with the Nepal government (Kantipur, 2021, para 13-28). On September 9, the vice president of MCC compact operations, Fatema Sumar, visited Kathmandu and met with Prime Minister Deuba and major political leaders to discuss the next steps in MCC implementation. On October 29th, MCC headquarters issued a press release showing concern over the delay in ratification by the Nepali parliament. Prime Minister Deuba also met with the deputy CEO of MCC, Ms. Alexia Latortue, on November 2, 2021, during his COP26 summit in Glasgow. On November 17, US Department of State Assistant Secretary for South and Central Affairs, Donald Lu, visited Nepal and discussed the longstanding MCC project with Nepali officials. The high-level visit and concern by US officials validate MCC's importance. As of today, the MCC remains uncertain as it hasn't been introduced into parliament amid differences between the major political parties of the ruling alliance.

\section{Literature Review and Methodology}

Few scholars have published about MCC and Nepal (Baniya, 2020, 2021; Chand, 2021; Jha, 2020; Pokhrel, 2021). Baniya (2020) argues that MCC is a soft power of the United States to counter China's Belt and Road Initiative ( $\mathrm{p}$. 65) and Nepal should accept MCC only if it respects Nepal's sovereign status and foreign policy goals (p. 45). Baniya's intention of prioritizing Nepal's foreign policy of nonalignment seeks avoidance in the competition among powers. But Hari Bansh Jha writes that competition has already started between the United States and China, which is delaying MCC in Nepal (Jha, 2020, para 4). Chand (2021) agrees with the competition and argues that Nepal will face geopolitical complexities in the future after accepting MCC and BRI (p. 13). However, Aditya (2021) acknowledges the benefits of MCC but questions the integrity and commitment of Nepal towards its implementation ( $p$. 13). Other scholars, except for Aditya, see MCC through the narrow lens of power competition and its geopolitical implications in Nepal. Geopolitics is an essential theme to understand MCC, but it is not sufficient to comprehend different interpretations in the bazaar. This paper attempts to present missing interpretations from the bazaar, explore different thematic areas of MCC, and describe its detailed implications for national security.

This paper follows an "interpretive" research methodology and comprehends popular interpretations of MCC in the bazaar. Here, "bazaar" refers to the non-governmental space of the media and television where experts depict their interpretations through audio, video programs, and social media. This study follows an inductive approach where, rather than residing within an existing theoretical 
framework, it collects secondary data from the bazaar through television interviews and conducts thematic analysis to construct a general set of themes about MCC. A series of experts from different fields of economics, politics, international relations, law, and governance are selected. The following are a few experts considered for this study: Bhim Rawal (politician and former home minister), Yubaraj Sangraula (academician and former attorney general), Sambhu Ram Simkhada (diplomat and former ambassador), Parsuram Kharel (senior journalist), Swarnim Wagle (economist), Semanta Dahal (lawyer), Surya Raj Acharya (infrastructure expert), Arun Subedi (businessman and analyst), and Krishna Gnawali (former bureaucrat).

\section{Thematic Analysis of the Interpretations of MCC}

The interpretations of MCC in the Nepali bazaar can be divided into three distinct themes. They are sovereignty, geopolitics, and governance. The theme of sovereignty covers interpretations by different experts that limit Nepal's autonomy and authority. Another theme of geopolitics predicts an increasing presence of global powers in Nepal. It sees the geography of Nepal, lying between the Tibetan Autonomous Region of China and India, as gaining increasing political influence. Some experts blame MCC for these geopolitical implications, whereas others interpret MCC as an opportunity to review Nepal's foreign policy. The third theme is governance, which views provisions of MCC and MCA-Nepal with pragmatism and attempts to clarify articles of MCC as an opportunity to overcome existing limitations of Nepali governance.

\section{Sovereignty}

Bhim Rawal argues that the MCC agreement infringes on the sovereign equality and autonomy of Nepal (AP1 HD, 2020d). He questions the preamble, Article 3.2.f, Article 5.1, Article 6.3.b, and Annex I.A.1.b of the MCC compact agreement. Similarly, he has also raised questions over 1.3.b.i, 1.3.b.viii, 5.4, and Schedule 2.A of the Program Implementation Agreement. Article 3.2.f of the Compact says that the Nepal government grants MCC the right to use intellectual property (Ministry of Finance, 2017, p. 6). Rawal associates this grant as an infringement of Nepal's sovereign rights to use its property (AP1 HD, 2020d). However, the term "grant" is explained differently by other experts. Semanta Dahal, an expert in international law, argues that "grant" means the government has allowed MCC to use intellectual property (AP1 HD, 2020a). Similarly, Rawal questions article 5.1.b.iv and Annex I.A.1.b of the compact agreement. Article 5.1.b.iv allows MCC to suspend or terminate the MCC agreement if the government, person, or entity receiving MCC funding is engaged in activities contrary to the national security interests of the United States (Ministry of Finance, 2017, p. 10). Annex I.A.1.b explains that MCC has worked closely with the United States Agency for International Development (USAID), the United States Department of State, the government of India, and a variety of partners to ensure the widest political support in identifying and designing the investments (Ministry of Finance, 2017, p. Annex I.2). Another politician, Raghu Pant, severely opposes Article 7.1 of the compact agreement which states that upon entry into force, the compact prevails over domestic law (Ministry of Finance, 2017, p. 13). Pant hints that the prevalence of the compact over 
domestic laws is against Nepal's will and sovereignty (AP1 HD, 2019).

Furthermore, experts also enquire about articles from the program implementation agreement. Article 1.3.b.i of this agreement says that MCA-Nepal has the power and authority to bind the government to the full extent of the designated rights and responsibilities (Ministry of Finance, 2019, p. 3). Dr. Yubaraj Sangraula claims this article and its provisions erode the sovereignty and autonomy of the government (AP1 HD, 2020b). However, Semanta Dahal argues that the government itself has formed MCANepal and designated it as a primary agent to implement the program and exercise the government's right and responsibility to oversee, manage, and implement the program (Ministry of Finance, 2019, p. 3). Sangraula says auditing of the MCA-Nepal expenses by a US-certified public accounting firm disdains Nepal's sovereignty as Nepal also contributes one hundred and thirty million USD to the fund (Shilapatra, 2019).

The abovementioned interpretations of MCC fall under the umbrella of sovereignty. Although there are a few disapprovals, the foremost narrative constructed from this theme is that MCC disdains the sovereignty and autonomy of Nepal.

\section{Geopolitics}

Rawal links MCC with the Indo-Pacific strategy and states that it contradicts Nepal's principles on the conduct of foreign policy. In the interview, he cites the following documents to demonstrate the relationship between Nepal, MCC, and Indo-pacific strategy: the $1986 \mathrm{AD}$ act by the Department of Defense, the 2019 AD report on Open and Free Indo-Pacific by the Department of State, the 2017 AD report on National Security Strategy by the White House, and the 2019 AD report on Indo-Pacific Strategy (AP1 HD, 2020d). The author was unable to locate the 1986 AD act, but the other three documents mention MCC. The White House (2017) report defines $\mathrm{MCC}$ as an incentive to reform countries and advance American influence (p. 39); the Department of State (2019) report defines MCC, including Overseas Private Investment Corporation (OPIC) and USAID, as economic pillars for the Indo-Pacific strategy (p. 13); and the Department of Defense (2019) positions Nepal under a state partnership program in the Indo-Pacific (p. 38). These US government published reports associate MCC with the Indo-pacific strategy, but they do not present MCC as any kind of security alliance or military pact. The MCC agreement itself forbids the use of funds for the assistance or training of the military, police, militia, national guard, or other quasimilitary organizations (Ministry of Finance, 2017, p. 4). As the Indo-pacific strategy by the USA and the Maritime Silk Route by China cover the same oceanic areas, both powers are competing in the Indian Ocean and the Pacific Ocean region with distinct policies. Rawal argues that in such context the MCC agreement might contravene Nepal's autonomy in the conduct of non-alignment foreign policy (AP1 HD, 2020d). Seemingly, Rawal places MCC inside the geopolitical theme and acknowledges the geopolitical implications of MCC in Nepal.

Yubaraj Sangraula argues MCC might exert influence on Nepal's non-alignment policy and toughen Nepal's balancing act between India and China (Shilapatra, 2019). In the same program, Sangraula links MCC with competition between the United States and China and argues MCC funding can be 
utilized in Nepal and Sri Lanka to eye the western parts of China. From a geopolitical standpoint, Sangraula interprets MCC as a US surveillance tool against China.

Senior journalist Parsuram Kharel also describes the geopolitical implications of MCC in Nepal. He suspects both China and India will become more active in Nepal and the northern region of India. $\mathrm{He}$ contends that the MCC will increase Chinese presence due to the sensitive Tibet autonomous region; communist China's strong presence in the region stimulates left political forces and Naxalite movements; as a result, India will increase its presence as it considers the Naxalite movement an internal threat (Ankur TV, 2021). The increasing and diverging interests of both neighbors, alongside the significant presence of the United States in this geography, will incite all forms of political forces in the region. Shambhu Ram Simkhada, a diplomat and former ambassador, acknowledges the complex, sensitive, and important context of geopolitics in Nepal (Simkhada, 2021, para 11). Political parties have their distinct political ideologies and schooling, which shape their global perspectives. Domestic liberal political parties and communist parties view the international system in different ways. In general, liberal parties comfortably affiliate with liberal international powers and communists with communist China, alongside an upsurge of nationalist forces to counter the increase of international powers, creating an unstable and coarse political competition. Arun Subedi, an author and analyst of international affairs, explicitly accepts the geopolitical containment strategy of the United States against China (AP1 HD, 2019). Although Subedi identifies MCC's geopolitical implications in Nepal, he views
MCC as an opportunity. He argues MCC has arrived as a gestation to review Nepal's existing foreign policy of non-alignment and equidistance (Galaxy 4K, 2021). In addition, international research centers have also acknowledged the geopolitical implications of MCC. An Observer Research Foundation (ORF) book on India-US relations says, like recent Japanese funds, MCC might act as a distinct funding mechanism different than China (Singh et al., 2018, p. 41).

Henceforth, there is consensus among experts that MCC brings unknown geopolitical inferences to the region. Some view it as a challenge, whereas others view it as an opportunity to amend Nepal's foreign policy.

\section{Governance}

After the September 11, 2001 attacks on the twin towers, America viewed poverty as a source of international terrorism. The genesis of MCC consists of the resolution of global poverty as a means of restraining international terrorism. Therefore, MCC is cautious regarding the status and efficacy of the governance of the aid-receiving country. In addition, MCC is a government aid agency that provides citizens' tax money as foreign aid to other countries. In the 2002 Monterrey speech, President Bush also emphasized that for a long period, resources spent were considered a measure of the success of aid rather than the results achieved. Hence, America formed the Millennium Challenge Corporation, along with USAID, to address transformations in international aid. Therefore, it is natural for them to be more cautious and thoughtful towards the governance of aid-receiving countries. Henceforth, governance becomes a significant theme in the interpretation of the MCC. 
Gnawali opts for a pragmatic and realistic observation of Nepali governance about the interpretation of the articles of MCC (AP1 HD, 2019). Article 1.3.b.iv of the program implementation agreement ensures that no decisions of the MCA-Nepal are modified, supplemented, unduly influenced, or rescinded by any government authority. Sangraula and Acharya interpret the phrase "unduly influence" as against the autonomy and supremacy of the government (AP1 HD, 2020b; Galaxy 4K, 2021). However, Gnawali links it with the theme of governance and presents an experienced insight into governance in Nepal. He says that institutions in Nepal face both visible and hidden challenges while implementing projects, and government changes follow with the substitution of heads of institutions and projects. A change in government has a turnover effect up to the undersecretary level, also including the chief of the Nepal Electricity Authority. Donor agencies criticize such high staff turnover in the project (AP1 HD, 2020a). Gnawali argues the word "unduly influence" is used in the agreement to prevent the projects from inappropriate and unfair influence. Henceforth, he presents a different perspective on the articles of the agreement from the theme of governance.

In addition, $\mathrm{MCC}$ envisions the completion of the project withinfiveyears of commencement. Five years is a challenging period to furnish a big infrastructure project. Besides, most infrastructure projects, including but not limited to Melamchi Drinking Water, Sikta Irrigation, Upper Tamakoshi Hydro Power, and Mid-hill Highway, have been delayed, leading to cost and time overruns. Nepal is gradually establishing a precedent of time and cost overruns in big infrastructure projects. Economist Swarmin Wagle states that tough and binding clauses are included in the agreement to meet the five-year timeline (AP1 HD, 2020c). Article 1.3.b.i of the program implementation agreement authorizes MCA-Nepal with the power to bind the government (Ministry of Finance, 2019 , p. 3). Gnawali argues that "power to bind" signifies authority and autonomy to work independently. Moreover, the tough timeline of project implementation also requires a disciplined institution with a sharp focus on the project.

Article 7.1 of the MCC compact agreement states that the agreement prevails over the domestic law of Nepal (Ministry of Finance, 2017, p. 13). There is also a general understanding that article 7.1 of the compact agreement prevails over the constitution of Nepal. Surya Raj Acharya explicitly asserts that this clause situates the compact agreement above the constitution of Nepal (Galaxy 4K, 2021). The necessity of parliamentary ratification of the MCC agreement also arose because of this clause. Swarnim Wagle states that the ministry of law and justice recommended parliamentary ratification (AP1 HD, 2020c). However, Semanta Dahal and Krishna Gnawali have different interpretations. Dahal cites an aidememoire, passed before finalizing article 7.1, which reads, "if the terms of the proposal are found to be in any conflict with any law of Nepal, other than the constitution of Nepal, the terms will prevail" (AP1 HD, 2020a, 2:39:46). Moreover, Gnawali approaches this clause through the theme of governance and explicitly denies its interpretation of prevalence over the constitution of Nepal. He explains that small domains of project implementation like land acquisition, compensatory settlement, procurement, supply of labor, and work permits might be 
stressful and create difficulty in practice. According to Gnawali, the prevalence of compact agreements over domestic law is to eliminate such practical difficulties in different project implementation domains (AP1 HD, 2020a).

Henceforth, governance exists as a significant theme in the interpretation of MCC. The origins of MCC aspire to the donor for assessment and evaluation of the receiving country's governance. The theme of governance opposes other thematic interpretations of sovereignty and autonomy.

\section{Implications for National Security}

The greatest challenge to national security is the inability to devise a consensus about MCC. There are diverse and opposing interpretations of MCC by different intellectuals, political parties, and leaders. The division is gradually progressing from political parties to diverging interpretations by ordinary people, which is a challenge to the national security of promoting unity among the people of Nepal.

The divergent interpretations discussed here stem from various thematic perspectives on the MCC. The autonomy of MCA-Nepal and its criticism arises from the theme of sovereignty for Bhim Rawal and Yubaraj Sangraula whereas the same autonomy of MCA-Nepal is a positive and pragmatic theme of governance for Krishna Gnawali. Similarly, the prevalence of the MCC compact over domestic law is subject to opposition from the theme of sovereignty for Surya Raj Acharya; whereas it is a provision to finish the project within the allocated five years from the theme of governance for Krishna Gnawali. Since different thematic perspectives are used in interpreting MCC, these differences can't be resolved via sectoral experts. Only political agreement among major political parties can produce such a synonymy. But, the political parties still have differences on the subject: The Nepali Congress proposes ratification by the parliament, whereas the Communist Party of Nepal, Maoist Center, and Unified Socialist intend ratification after amendments and national consensus. Moreover, small left political parties disprove MCC and describe it as a United States strategy against China based on the theme of geopolitics. It seems the consensus among parties is still far away, but the division among people is escalating. The opponents of MCC reprimand its supporters with abusive words and accusations of antinational objectives. Similarly, the supporters accuse the opponents of hindering the prosperity of the people. Such scathing reproaches further divide society and instill a sense of threat among its members. A timely political consensus on divergent interpretations of MCC on different themes is critical to preserving Nepalese national unity.

Another implication to national security stems from the theme of geopolitics. The MCC enhances American engagement in the critical infrastructure of the region, resulting in increased interest from both neighbors, India and China. An increase in engagement and interest demands stable domestic politics and foreign policy equivalence. Historically, Nepal has successfully managed geopolitical interests and competition among powers during the war between neighbors in 1962; changes in the political geography of South Asia during the cold war; and the peace process after 2005 AD. However, the current challenge to national security arises from the "narrative" being constructed against MCC. Some Nepali politicians, scholars, and experts are propagating the narrative of MCC as the 
United States against China. This narrative, interpreted by the Nepali themselves, presents MCC as a tool of the United States for Chinese containment and advocates rejection of MCC on this ground. The aforesaid narrative cautions both China and India, increase their interests and engagement, and questions the credibility of the diplomatic and security institutions of Nepal. The significant rise in this narrative has demonstrated the great interests of both China and the United States in Nepal. The visit of Fatema Sumar and the meeting between Prime Minister Deuba and the deputy CEO of MCC authenticates American interests. The aforesaid narrative, linking China with MCC, is responsible for the explicit reaction by Chinese scholars and journalists. Shengping Zhou, former Xinhua news bureau chief in Kathmandu, states that MCC has too many strings attached to it (Zhou, 2021, para 13). The Global Times reporter Wang Yi writes that MCC aspires to counter the influence of the BRI (Wang, 2021, para 6). Similarly, Zhan Sheng, a research fellow at the Chengdu Institute of World Affairs, stages MCC as anti-China and argues it will harm the feelings of Chinese people (Sheng, 2021, para 18). Such prescriptions by both powers flout Nepal's principles of foreign policy based on Panchasheel, non-alignment, and developing external relations in the interest of Nepal, which are the fundamental objectives of Nepal's national security. Henceforth, narratives being developed on the geopolitical theme could pose a challenge to Nepal's principle of conducting foreign policy based on its national interest. Our inability to create trust in our political, security and diplomatic institutions to both China and United States would amplify their role in the conduct of our foreign policy. Therefore, Nepal shall construct the narrative as "Nepal is independent to select international support based on its national interest and equally committed not to allow its soil to be used for any inimical activities against neighbors."

The third challenge to national security arises from a gap in the interpretation of the MCC. The thematic analysis discovered three themes of sovereignty, geopolitics, and governance from expert interpretations in the bazaar. A fundamental gap resides in interpreting MCC from the perspective of economic development. The compact agreement stipulates benefits for 23 million individuals and estimates an economic rate of return (ERR) of $12 \%$ for electricity transmission project and $29 \%$ for road maintenance project (Ministry of Finance, 2017, pp. I.2-I.3). However, there are no discussions in the bazaar regarding MCC's impact on Nepal's Gross Domestic Product (GDP), poverty alleviation, employment generation, and the resolution of the trade deficit with India. Until December 14, 2021, Nepal's economy was struggling with a liquidity crisis in commercial banks, a credit-to-debt ratio (CDR) that exceeded the regulatory limit of $90 \%$, low capital expenditure, current account deficits, and declining remittances. The country's total debt has increased from $20.6 \%$ in the fiscal year of $2016-2017 \mathrm{AD}$ to $40.72 \%$ in the fiscal year of 2020-2021 AD (Public Debt Management Office, 2021, p. 1). The MCC aid program is not sufficiently discussed from the economic development perspective amid vulnerable economic indicators in the country. People are not discussing the possibilities of employment, entrepreneurial activities, the status of transportation, and changes in the cost of electricity and transportation after MCC projects. The shading of the economic development perspective has shadowed opportunities related to employment and 
poverty alleviation, which are the socioeconomic challenges of national security policy.

\section{Conclusion}

This paper presents an inductive thematic analysis of MCC in Nepal. It observes that current interpretations of $\mathrm{MCC}$ reside in three themes: sovereignty, geopolitics, and governance. These themes help to identify the national security implications of MCC interpretations in Nepal. Diverging interpretations based on divergent themes have created political division and exacerbated differences at the personal level. It creates a challenge to national unity among the people of Nepal. In addition, the narrative of the United States against China, constructed by Nepali experts themselves, has increased interest in both the United States and China in Nepal. Lastly, the inability to discuss MCC from an economic development perspective creates socio-economic challenges related to poverty and employment.

\section{References}

Aditya, A. (2021). Regime Capability and Relational Stakes in the Emerging World Order. Journal of Foreign Affairs, 1(1), 1-36. doi:10.3126/jofa.v1i1.36247

Ankur TV. (2021, August 24). Sensational Revelation about MCC, China, and Military. [Video]. YouTube. https://www.youtube.com/ watch? $\mathrm{v}=\mathrm{C} 8 \mathrm{mUiYX} 3 \mathrm{RJU}$

AP1 HD. (2019, Jun 15). अमेरिकी सहयोग एमसीसीको विवाद के हो ? [What is the dispute over MCC? ]. [Video].YouTube. https://www.youtube.com/ watch? $\mathrm{v}=$ abyh63APH4I

AP1 HD. (2020a, June 16). एमसीसी सन्देह, संवाद र समाधान. [MCC: Doubt, Dialogue, and Solution] [Video]. YouTube.https://www.youtube.com/ watch?v=uUCWGbhpdGA
AP1 HD. (2020b, February 8). एमसीसी यही अवस्थामा पारित भए के हुन्छ ? [What happens if MCC passes in current status?]. [Video]. YouTube. https://www. youtube.com/watch? $\mathrm{v}=\mathrm{NlsKDsR3Tj8}$

AP1 HD. (2020c, June 1). कोरोना कहरबीच आएको बजेट ₹ ओली सरकारको समीक्षा [Review of Oli government and budget amid corona]. [Video]. YouTube. https://www.youtube.com/ watch?v=F9SBfaKIgZc

AP1 HD. (2020d, June 15). यस कारण म एमसीसीको विपक्षमा [Why am I against MCC] [Video]. YouTube. https://www.youtube.com/ watch?v=7hpz9jrb3QA

Baniya, D. B. (2020). Geo-strategic importance of Nepal. Unity Journal, 1(0), 39-47. doi:10.3126/ unityj.v1i0.35693

Baniya, D. B. (2021). Soft Power in the Contemporary World: Recommendations to the Small States' Security. Unity Journal, 2(0), 54-69. doi:10.3126/unityj.v2i0.38809

Chand, H. P. (2021). Nepal's Engagement in BRI and MCC: Implications on Nepal's Geopolitics and Foreign Policy. Journal of Political Science, 21(1), 60-77. doi:10.3126/jps.v21i1.39288

Department of Defense. (2019). Indo-Pacific Strategy Report Preparedness, Partnerships, and Promoting a Networked Region. Washington, D.C.: U.S. Government. https://media. defense.gov/2019/Jul/01/2002152311/-1/1/1/DEPARTMENT-OF-DEFENSE-INDOPACIFIC-STRATEGY-REPORT-2019.PDF

Department of State. (2019). A Free and Open Indo-Pacific Advancing a Shared Vision. Washington, D.C.: U.S. Government .https:// www.state.gov/wp-content/uploads/2019/11/ Free-and-Open-Indo-Pacific-4Nov2019.pdf

Galaxy 4K. (2021, November 7). एमसीसी फर्किए आफनै खुट्टामा उभिन्छ -आचार्य, फर्काउनेलाई राष्ट्रद्रोहका मुद्दा -सुवेदी [Stand on our own feet if MCC returns - Acharya; Treason to the responsibles of return Subedi]. [Video]. YouTube. https://www.youtube. com $/$ watch? $\mathrm{v}=$ pEomFZHYYdc 
Jha, H. B. (2020, January 12). Rivalry between US and China in Nepal delays MCC. ORF. https:// www.orfonline.org/expert-speak/rivalry-between-us-and-china-in-nepal-delays-mcc-60298/

Kantipur. (2021, September 9). Nepal government's offensive questions regardig MCC [एमसीसीबारे सरकारका आपत्तिजन प्रश्न]. Ekantipur. https://ekantipur.com/news/2 021/09/09/163114932724283118.html? fbclid=IwAR2fB3DKRkeParSvUlGvdDodjrG69mDD1pmpxmh66un7QBqlZN5LAoubP5c

Millennium Challenge Corporation. (2021, n.d.). About MCC. https://www.mcc.gov/about

Ministry of Defense. (2016). National Security Policy 2016. Kathmandu: Nepal Government

Ministry of Finance. (2017). Millennium Challenge Compact Between The United States of America Acting through The Millenium Challenge Corporation and The Federal Democratic Republic of Nepal Acting through The Ministry of Finance. Kathmandu: Ministry of Finance https://mcanp.org/en/documents-reports/mainagreements/

Ministry of Finance. (2019). Program Implementation Agreement between The United States of America acting through The Millenium Challenge Corporation and The Federal Democratic Republic of Nepal acting through The Ministry of Finance. Kathmandu: Ministry of Finance https://mcanp.org/en/documents-reports/ main-agreements/

Pokhrel, K. P. (2021). Nepal-China-India Relation: A Geostrategic Perspective. Journal of APF Command and Staff College, 4(1), 28-40. doi:10.3126/japfcsc.v4i1.34134

Public Debt Management Office. (2021). Yearly Report of Nepal Government's Public Debt. Kathmandu: Nepal Government https://pdmo. gov.np/noticedetail/84/2021/50914091

Sheng, Z. (2021, September 17). Improving Nepal-China relations: MCC isn't a wise choice; the border issue shouldn't be politicized. Onlinekhabar. https://english.onlinekhabar.com/ zhan-sheng-nepal-china-relations.html
Shilapatra. (2019, December 24). MCC is an American Security Strategy. [Video]. YouTube. https://www.youtube.com/watch?v=yt98F1E3rCI Simkhada, S. R. (2021, December 15) Nepal is diplomatically unreliable. Whom should India, China, and US trust?" [नेपालमा कुटनीतिक अविश्वसनीयता छ, भारत, चीन र अमेरिकाले कसलाई विश्वास गर्ने ?]/Interviewer: M. Dahal. Ekantipur, Kantipur Publications, Kathmandu.

Singh, A., Pande, A., Smith, J. M., Saran, S., Joshi, S., \& Lohman, W. (Eds.). (2018). The New India-US Partnership in the Indo-Pacific: Peace, Prosperity, and Security. New Delhi: Observer Research Foundation.

The White House. (2017). National Security Strategy of the United States of America. Washington, D.C.: The White House https:// trumpwhitehouse.archives.gov/wp-content/ uploads/2017/12/NSS-Final-12-18-2017-0905. pdf

U.S. Embassy in Nepal. (2021). MCC Vice President Fatema Sumar visits Nepal [Press release].https://np.usembassy.gov/media-notemcc-vice-president-fatema-sumar-visits-nepal/

Uprety, B. R. (2019). Security for Enhancing Peace and Stability in Changing Context of Nepal. Journal of APF Command and Staff College, 2(1), $1-13$.

Wang, Y. (2021, November 21). US can't undermine regional interconnection with an aid project to Nepal. Global Times. https://www. globaltimes.cn/page/202111/1239715.shtml

Zhou, S. (2021, September 20). Geopolitics of MCC. Lokantar. https://english.lokaantar. com/news/detail/24128/?fbclid=IwAR1IP9bjz FeouQyZofpo5kCoji6WK4UV8GuhDSZhZy_88fZBhHLpfhTAw0 